\title{
Development of energy companies in a digital environment, taking into account business risk factors
}

\author{
Irina Kazmina ${ }^{1, *}$, Valentina Rodionova ${ }^{2}$, Tatiana Shchegoleva ${ }^{2}$, Olga Muratova $^{3}$, and \\ Oleg Sudakov ${ }^{3}$ \\ ${ }^{1}$ Military educational scientific center air force air force Academy named after professor N. E. \\ Zhukovsky and Y. A. Gagarin, St. Old Bolsheviks, 54 "A", 394064, Voronezh, Russia \\ ${ }^{2}$ Voronezh state technical University, Moscow avenue, 14, Voronezh, 394006, Russia \\ ${ }^{3}$ Voronezh State Medical University named after N.N. Burdenko of the Ministry of Health of the \\ Russian Federation, 10 Studencheskaya Street, 394036 Voronezh, Russia
}

\begin{abstract}
The paper deals with the development of energy companies, taking into account business risk factors. It has been established that the identification and assessment of business risk factors makes it possible to identify areas of development on which it is advisable to focus the available management resources of energy companies. The paper discusses the assessment of business risks in the framework of design work, which play a key role in the implementation of development programs for individual functional subsystems of energy companies. The presented descriptive model of the formation of the reaction of the management of a high-tech enterprise to the occurrence of risk is based on the subject's ideas about risk. At the same time, it was determined that the line between acceptable and unacceptable for the enterprise level of risk in the implementation of priority areas of development in different periods of the enterprise's life cycle is different. The identification of business risk factors results in a list of risk factors for energy companies, which is presented in the paper by two groups reflecting internal and external factors. Risk identification is carried out in accordance with the process of detecting and establishing temporal, quantitative and spatial characteristics that are necessary and sufficient for the development of preventive and operational measures aimed at ensuring the effective implementation of the risk management process.
\end{abstract}

\section{Introduction}

The development of companies in the energy industry should be adequate to the changing conditions. In this regard, it becomes impossible to use the same management tools in the dynamism of the digital environment. In the digital economy, the functioning of energy companies is based on the strategic goals of ensuring development and adaptation to new production conditions. This is caused by the fact that digitalization is changing the views on

\footnotetext{
${ }^{*}$ Corresponding author: kazminakazmina@yandex.ru
} 
conventional management approaches as a result of increased competition and the expansion of the globalization of the economy. Energy companies are required to synthesize existing management methods and tools that allow them to quickly respond to changing market conditions. The question of the search for criteria by which it would be possible to determine the optimal areas for the development of energy companies is highlighted. One of these key criteria is the level of business risk. Identification and assessment (qualitative and quantitative) of factors of business risk will reveal the areas of development, on which it is advisable to focus the available management resources of energy companies.

Planning the development of energy companies through the prism of business risk allows obtaining information about the possibility of adverse situations in the process of functioning of energy companies in the digital environment.

Especially actively the assessment of business risks is used in the implementation of design work, which play a key role in the implementation of development programs for individual functional subsystems of energy companies. According to the project approach, the following sub-processes are traditionally distinguished within the framework of business risk management [1-2]:

1. Identification of business risks

2. Qualitative assessment of business risks.

3. Quantitative assessment of business risks;

4. Development of measures aimed at responding to business risks;

5. Monitoring and control of business risks.

All of these sub-processes are implemented using a serial-parallel approach. At the same time, the management of entrepreneurial risks within the framework of the project approach has some drawbacks. In a digital dynamic environment, more and more environmental factors appear, which determine the possible emergence of completely new entrepreneurial risks. In this regard, it is not always advisable to use the methodological foundations of the project approach when developing energy companies $[1,3]$.

\section{Materials and Methods}

Business risk management in the implementation of activities related to the development of energy companies in the digital environment is aimed at minimizing risks to an acceptable level for a given company.

Determination of the acceptable value of the level of business risk is the task of the top management of energy companies. The line between acceptable and unacceptable for the enterprise level of risk in the implementation of priority areas of development in different periods of the life cycle of the enterprise and in different sectors of the economy is different.

In every economic system, a person plays a special role. This causes the problem of subjectivity in assessing business risks. That is, in addition to the objective side of understanding the essence of risk, subjective ideas often arise about the occurrence of various risks. At the same time, in some cases, the subjective component is much more important when assessing risks [4-5].

Figure 1 shows a descriptive model of the formation of the reaction of the management of the energy industry companies to external factors of the digital environment when implementing measures related to development and based on the subject's ideas about risk. 


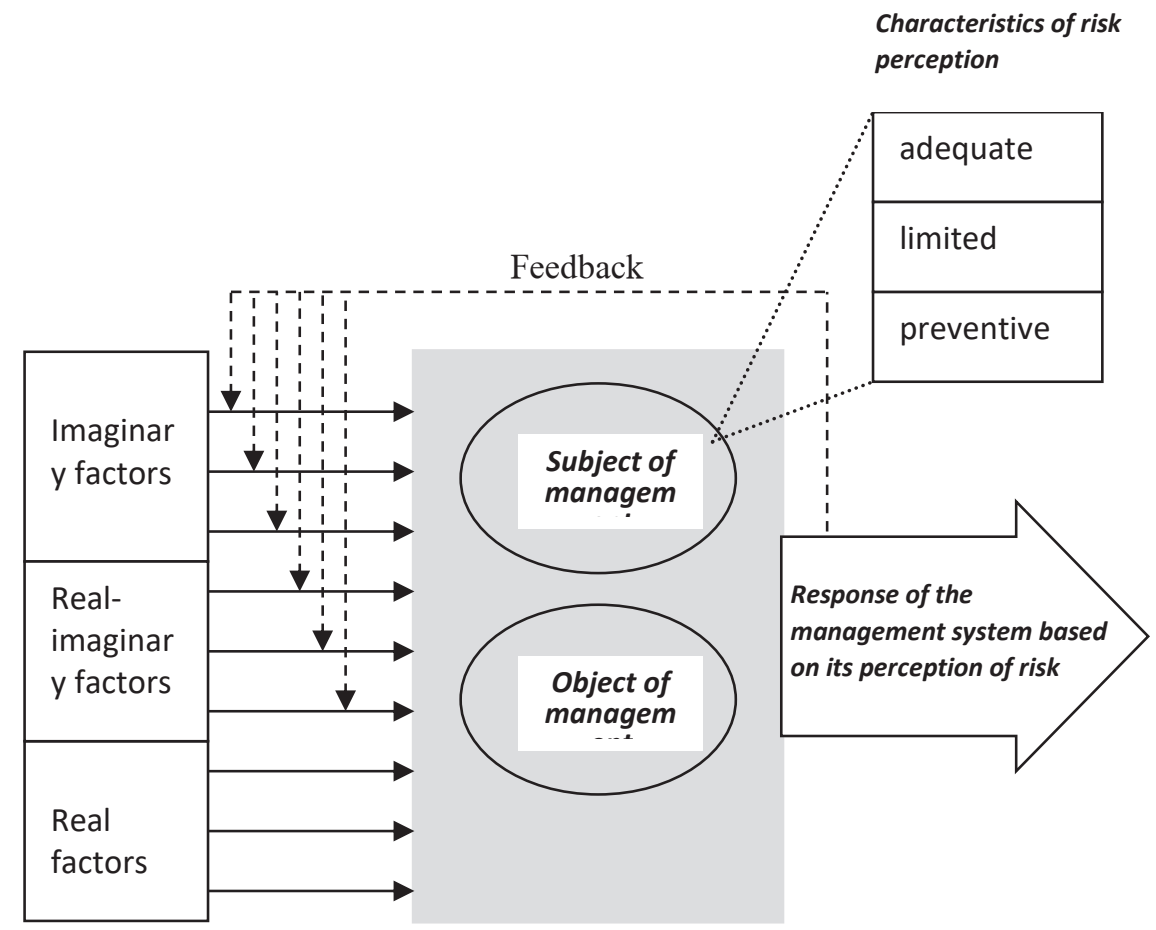

Fig. 1. Descriptive model of the formation of the reaction of the management of an energy company to the occurrence of risk

A number of factors of the external digital environment that affect the perception of the level of business risk have an objective basis, and ideas about them are not reliable. Therefore, such factors are called real.

The next part of the factors is of a double nature. On the one hand, it has a real, reliable basis, while on the other hand, there is a distortion of information associated with the factors handed over in the process of its transmission. Such factors can be considered real-imaginary. And the third part of the factors is completely imaginary, i.e. it is distorted by the subject based on his subjective ideas. And such factors are imaginary [6, 7].

The most objective assessment of emerging risks in the development of energy companies makes it possible to use an indicative approach.

An energy company is a complex dynamic system that includes many functional subsystems.

All the diversity and multidirectionality of economic, technological and social processes occurring in an energy company can be viewed from the standpoint of a set of indicators. It is advisable to group the indicators into the following blocks: production volumes, manufactured products; marketing, product prices and market conditions; effectiveness of innovation; product quality and competitiveness; internal potential; production capacity and equipment performance; depreciation and the degree of renewal of production assets; revolving funds; personnel potential, working hours; labor standards, labor intensity and labor productivity; wages and working conditions; enterprise management; diversification of production; production costs, profit and profitability of the enterprise; key factors and reserves of efficiency growth [8-10].

The most informative indicators for the analysis of business risk factors, due to their availability and the possibility of interpreting the results, are the financial performance 
indicators of energy companies, reflecting profitability, business activity, financial stability and liquidity.

The identification of business risk factors results in the identification of a basic list of business risk factors for energy companies. This list is presented in Table 1.

Table 1. Basic list of business risk factors

\begin{tabular}{|l|}
\hline \multicolumn{1}{|c|}{ Business risk factors } \\
\hline External factors \\
\hline 1.1 Political stability of the country \\
\hline 1.2 Social stability \\
\hline 1.3 Breach of contracts by local or federal government authorities \\
\hline $\begin{array}{l}\text { 1.4 Negative change in prices (rise in prices) for raw materials, materials, } \\
\text { components, energy resources }\end{array}$ \\
\hline 1.5 Falling effective demand for basic science-intensive products \\
\hline 1.6 Emergence of new competitors in the same market sector \\
\hline $\begin{array}{l}\text { 1.7 The emergence of a new technology of high-tech production at a lower cost by } \\
\text { competitors }\end{array}$ \\
\hline 1.8 Tightening of environmental requirements in the region \\
\hline 1.9 Exposure to hostile takeover \\
\hline $\begin{array}{l}\text { 1.10 Disruption of communication between enterprises as subjects of the digital } \\
\text { environment }\end{array}$ \\
\hline Internal factors \\
\hline 2.1 Breakdown of main equipment \\
\hline 2.2 Breakdown of auxiliary production equipment \\
\hline $\begin{array}{l}\text { 2.3 Unpreparedness of tool facilities and technological equipment for changing the } \\
\text { manufactured product }\end{array}$ \\
\hline 2.4 Violation of discipline by personnel \\
\hline 2.5 Existence of opportunities for economic abuse and crime \\
\hline 2.6 Leakage of confidential information through technical channels \\
\hline $\begin{array}{l}\text { 2.7 Insufficient patent protection of the company's products and technology of its } \\
\text { manufacture }\end{array}$ \\
\hline 2.8 Insufficient level of provision of information necessary for work \\
\hline 2.9 Lack of leadership qualifications \\
\hline 2.10 Inadequate formulation of the company's own strategic goals \\
\hline 2.11 Inadequacy of innovation policy \\
\hline 2.12 Inadequacy of the investment activity of the enterprise \\
\hline
\end{tabular}

\section{Evaluation}

For the stable operation of an energy company in a digital environment, it is necessary to systematically carry out measures to reduce the level of business risk.

The development of methods for reducing business risks requires identifying the key factors that generate it, as well as assessing their significance. The analysis of business risks is carried out on the basis of a qualitative (orientation towards the identification of factors and types of risk) and quantitative (determination of the size of certain types of risk and risk in the whole enterprise) assessment of the identified risks.

Risk identification is carried out in accordance with the process of detecting and establishing temporal, quantitative and spatial characteristics that are necessary and sufficient for the development of preventive and operational measures aimed at ensuring the effective implementation of the risk management process. As a result of identification, the range of 
business risks, the likelihood of their occurrence, spatial localization, as well as the possible damage from the occurrence of a risky event are revealed [11].

A study conducted by the McKinsey consulting firm showed that $65 \%$ of quantitative parameters affecting the efficiency of American companies in the energy industry are internal and are under the control of management, and 35\% are external factors outside of its control, which are an objective feature of the digital environment [ 12.13].

For the Russian unstable economy, it is advisable to take into account both internal and external factors, as well as to understand the significance and interaction of external and internal factors affecting the energy company. In order to successfully develop in a digital environment, a company in the energy industry must implement management decisions with a complexity and speed that exceeds the complexity and frequency of changes in the external digital environment. Therefore, for effective functioning in the context of the digital transformation of an energy company, it is necessary to provide such organizational conditions so that any external changes can be neutralized at the expense of the company's internal potential.

\section{Conclusions}

Thus, the dynamic development of the digital environment determines the need for control systems focused on a wider range of tasks, allowing the tracking and management of a large number of economic objects and relationships. One of the key tasks is to organize the activities of an energy company associated with identifying business risks and developing measures to mitigate them. It is recommended to consider all the diversity and multidirectionality of economic, technological and social processes occurring in an energy company and affecting the emergence of business risks from the standpoint of a set of indicators divided into groups.

\section{References}

1. D. Gelai, M. Kroui, V. B. Minasyan, R. Mark, Osnovy risk-menedzhmenta, 390 (Moscow, Izdatel'stvo YUrajt, 2019)

2. V. N. Vyatkin, Risk-menedzhment : uchebnik, 2-e izd., pererab. i dop., 365 (Moscow, Izdatel'stvo YUrajt, 2019)

3. I. V. Kazmina, C. Y. Shafranskaya, I. I. Saenko, S. I. Kozhemov, S. R. Gayazova, E. I. Zatsarinnaya, An economic security management system of an enterprise in the digital economy, Talent Development and Excellence, 12(3), 454-466 (2020)

4. L. V. Agarkova, Upravlenie finansovymi riskami korporaciya, Alleya nauki, 4, 1(17), 561-564 (2018)

5. I. V. Kazmina, The Mechanism of Interaction of Virtual Companies with the Companies of Various Forms Manufacturing Technically Sophisticated Products, Advances in Economics, Business and Management Research, Proceedings of the Russian Conference on Digital Economy and Knowledge Management, 148, 268-273 (RuDEcK, 2020)

6. E. R. Borisova, Problemy metodologicheskogo obosnovaniya upravleniya finansovymi riskami, Vestnik Rossijskogo universiteta kooperacii, 4(30), 18-20 (2017)

7. I. V. Kaz'mina, Vliyanie cifrovyh informacionnyh tekhnologij na povyshenie konkurentosposobnosti vysokotekhnologichnyh predpriyatij, Vestnik voronezhskogo gosudarstvennogo universiteta inzhenernyh tekhnologij, 82, 2(84), 174-180 (2020) 
8. N. V. Smorodinskaya, Globalizirovannaya ekonomika: ot ierarhij k setevomu ukladu, 344 (Moscow, IE RAN, 2015)

9. V. L. Suponickij, M. I. Kuternin, Ya. D. Vishnyakov, Sozdanie aktivnogo elementa novoj otrasli ekonomiki znanij - cifrovoj ekonomiki, Vestnik universiteta, 4, 99-106 (2020)

10. R. Golov, V. Smirnov, T. Narezhnaya, A. Ovsyannikova, E. Zhutaeva, E. Sizova, T. Makeeva, Adaptation of industrial and energy enterprises to the im-plementation of the concept of open innovation, E3S Web of Conferences, 21- 30 (2019)

11. V. V. Shevchenko, K voprosu o sushchnosti ekonomicheskoj adaptacii, Vestnik instituta ekonomicheskih issledovanij. Izdatel'stvo «Institut ekonomicheskih issledovanij», Doneck, 1(1), 20-39 (2016)

12. T. Tolstykh, D. Savon, E. Shkarupeta, A. Safronov, O. Savelyeva, The digital transformation laboratory as an integral part of the national university of science and technology «misis» development strategy. Proceedings of the 33rd International Business Information Management Association Conference, IBIMA 2019: Education Excellence and Innovation Man-agement through Vision 2020, 8443-8452 (2019)

13. S. S. Morkovina, V. I. Mikhin, D. A. Timashchuk, Priority investment projects in the forestry complex: assessment and implementation prospects. V sbornike: Proceedings of the 33rd Internation $\neg$ al Business Information Management Association Conference, IBIMA 2019: Edu $\neg$ cation Excellence and. Innovation Management through Vision 2020-2019, 1677-1683 